Review Article

\title{
An Update on the Preventive Outlook for Supplementation of Vitamin-D against SARS-CoV-2 Infection
}

\section{Abu Saim Mohammad Saikat ${ }^{1,2}$, Muhammad Torequl Islam ${ }^{3}$}

${ }^{1}$ Department of Biochemistry and Molecular Biology, Faculty of Life Sciences, Bangabandhu Sheikh Mujibur Rahman Science and Technology University, Gopalganj 8100, Bangladesh; asmsaikat.bmb@gmail.com, https://orcid.org/0000-0002-6850-1245

${ }^{2}$ Laboratory of Computational Biosciences (LCB), Advanced Bioscience Research Center (ABRC) Gopalganj 8100, Bangladesh

${ }^{3}$ Department of Pharmacy, Lfe Science Faculty, Bangabandhu Sheikh Mujibur Rahman Science and Technology University, Gopalganj 8100, Bangladesh; dmt.islam@bsmrstu.edu.bd; https://orcid.org/0000-0003-0034-8202

*Correspondence: asmsaikat.bmb@gmail.com (Abu Saim Mohammad Saikat)

\begin{abstract}
The pandemic novel coronavirus disease 2019 (Covid-19) has a high death rate, which threatens nearly most of the world's population. The main reason for mortality in severe acute respiratory syndrome is intensified inflammatory activity followed by oxidative stress and inflammatory reactions in the lungs. To date, this pathology does not have a clear and conclusive cure, troubling the world population, particularly elderly adults, who are the major risk group. In this sense, assessing the effectiveness of current pharmacological agents, which can be used to resolve or attenuate this pulmonary complication's seriousness that has threatened the lives of so many people globally, is of particular importance. In contrast to quarantine, public health interventions are urgently needed to reduce the risk of illness and death. Evidence reveals that vitamin D supplementation may be possible in treating Covid-19. Additionally, numerous trials and studies
\end{abstract}


have started to study the effect of vitamin D supplementation on patients with SARS-CoV-2 infection.

\section{Keywords}

Covid-19, SARS-CoV-2, Vitamin D, Oxidative stress, Inflammation

\section{Introduction}

In late December 2019, China announced growing pneumonia in Wuhan City, Hubei Province. In January 2020, the trigger was a novel beta coronavirus (CoV) [1]. When the virus was initially reported in December 2019 as causing pneumonia in Wuhan, China, it was designated as a 2019 novel coronavirus (2019-nCoV). When further data and genetic analysis become accessible, the International Committee for Virus Taxonomy gave the virus the official title of severe acute coronavirus 2 (SARS-CoV-2), when the WHO called the virus-caused disease novel coronavirus disease 2019 (Covid-19). SARS-CoV-2 is easily distributed from individual to individual, allowing it to expand exponentially in the globalized world.In the ensuing Covid-19 pandemic, 57,514,482 people were infected, and 1,371,583 patients died (as of November 21, 2020, source:

Johns Hopkins University). As an emerging acute respiratory infectious disease, Covid-19 predominantly spreads across the airway, respiratory secretions, droplets, and direct contact [2]. Moreover, SARS-CoV-2 was confirmed to be derived from faecal swabs and blood, suggesting the likelihood of several transmission paths [2,3]. However, thisrequires more interpretation. Every SARS-CoV-2 virion has a diameter of 50-200 nanometers [4]. SARS-CoV-2 contains four proteins in its structure, including spike $(\mathrm{S})$, membrane $(\mathrm{M})$, envelope $(\mathrm{E})$, and nucleocapsid $(\mathrm{N})$ 
proteins (Figure 1). The N protein contains the RNA genome, and the viral shell is formed by $\mathrm{S}$, E, and M proteins combined. The spike (S) protein that has been described at the atomic level using the microscope of the cryogenic electron is the protein that enables the virus to bind and fuse with a host cell membrane; in particular, its S1 unit precipitates the S2 unit of the combination [57].

There is increasing evidence that the supplementation of vitamin D (VD) could theoretically be beneficial in the prevention and treatment of Covid-19 [8-11]. Indeed, the effects of VD supplementation on Covid-19 patients have already been studied, and even trials (summarized in Table 1) have been introduced. Although these trials' findings will be available in the foreseeable future and offer precious knowledge as to the advantage of these patients with VD supplementation, the processes by which VD exercises its ability remain mostly mysterious. Here, we update VD's role in various Covid-19 outcomes, which are based on potential processes of action [12, 13]. 

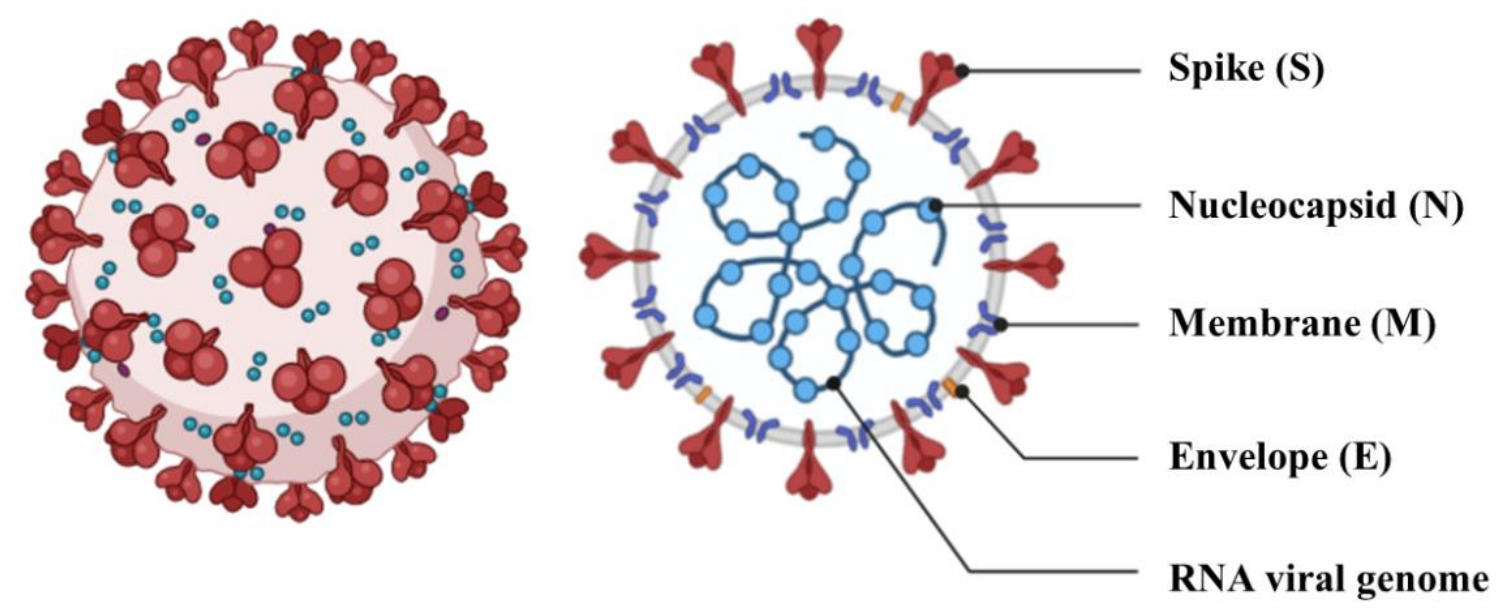

Figure 1. Structure of SARS-CoV-2

\section{Source and metabolism of vitamin D}

Vitamin D (VD) is a life-saving fat-soluble steroid in higher animals. The direct effect of ultraviolet ( UV) sunlight induces VD mainly in the skin, with the far smallest proportion deriving from nutrient intakes $[14,15]$. Ergocalciferol $\left(\mathrm{VD}_{2}\right)$ and cholecalciferol (VD3) are the two primary forms of VD. Due to the lack of naturally occurring VD-rich foods, VD2 is widely applied to foods, while $\mathrm{VD}_{3}$ is often produced on the skin, but it can also be detected in animal-based foods [14]. Considering the VD dermal production mechanism, cutaneous 7-dehydroxycholesterol is photolytically converted to pre-vitamin $\mathrm{D}_{3}$ by UV sunlight. Pre-vitamin $\mathrm{D}_{3}$ then undergoes an instant, non-enzymatic temperature-determined isomerization to form $\mathrm{VD}_{3}[16,17]$. VD covers a variety of phases to be converted into calcitriol $(1,25(\mathrm{OH}) 2-\mathrm{VD})$, the bioactive metabolite of VD, 
regardless of its source [17]. The ultimate constructive framework of VD appears mainly in the kidney, concerning the second hydroxylation mechanism in which the enzyme $1 \alpha$-hydroxylase (also referred to as CYP27B1) transforms 25(OH)-VD to 1,25(OH)2-VD [18].

In humans, vitamin $\mathrm{D}_{3}$ (also referred to as cholecalciferol), as well as vitamin $\mathrm{D}_{2}$ (well-known as ergocalciferol), are essential nutrients [19]. Cholecalciferol is a type of steroid hormone generated in the skin whenever it is exposed to UV radiation or food sources. In preserving blood calcium, phosphorus (P), and bone mineralization, 1,25-dihydroxycholecalciferol (also referred to as calcitriol) plays an essential function in the active form of cholecalciferol [20]. Enabled cholecalciferol connects and upregulates gene expression to vitamin D receptors. This results in increased serum calcium content by rising intestinal phosphorus and calcium absorption, facilitating distal renal tubular calcium reabsorption, and increased osteoclastic resorption. Ergocalciferol is an analogous vitamin D found in an inactivated form. It is formulated with UVB light by individual plants. Ergocalciferol synthesis was motivated by recognizing a dietary shortage, particularly vitamin D, as the primary cause of rickets formation $[14,20]$. 


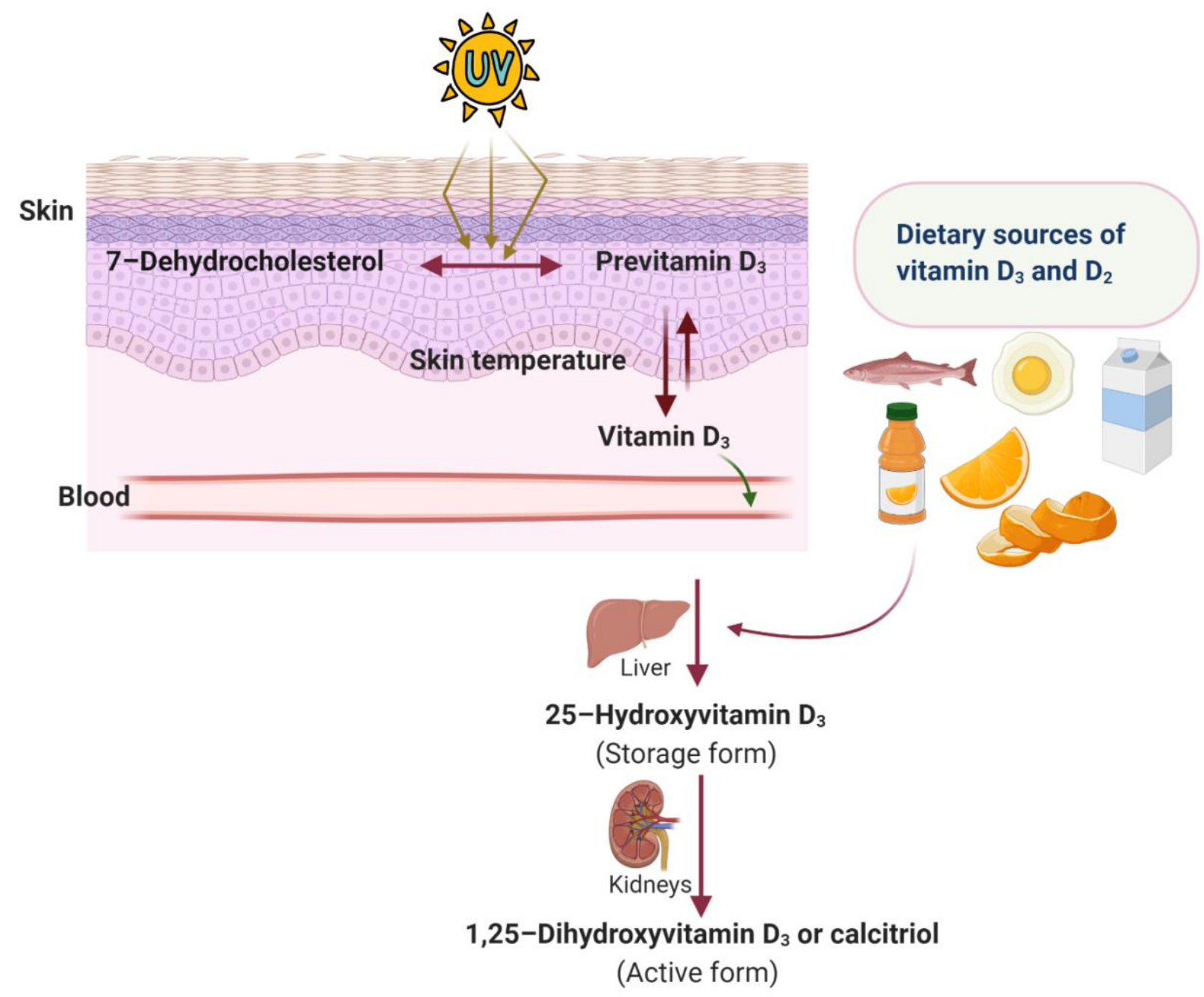

Figure 2. Vitamin D metabolism

\section{Preventive outlook of vitamin D}

Vitamin D and Tuberculosis

Mycobacterium tuberculosis is a bacterium that most commonly damages the lungs and induces tuberculosis (TB). TB can be treated and removed. TB is transmitted through the air from individual to individual. When people sneeze, cough, or spit with lung tuberculosis, they spur the 
TB germs into the air. Just a portion of these pathogens must be inhaled to become infected [21,22]. TB is astonishingly one of the deadliest diseases and is graded worldwide above HIV/AIDS. One hundred ninety-eight countries \& territories, accounting for greater than $99 \%$ of the global population with the number of tuberculosis cases estimated, published reports in 2020 [23].The number of TB-infected patients worldwide was reported at 10.0 million (range, 8.9-11.0 million) in 2019, a slowly decreasing rate in recent years [23].

The first effort was made in 1849 to use VD supplementation to treat TB [24,25]. After a few days of therapy with fish liver oil, 234 TB cases improved their conditions [25]. In 1950, Charpy first used pharmacological doses of VD2 to treat cutaneous TB after identifying VD's composition [24]. Furthermore, the hypercalcemia level recorded in the studies analyzed here was deficient [26,27]. Even though VD supplements are not associated explicitly with VD supplements, three new cases of paradoxical uprising feedbackin patients assigned to VD classes have been identified. Finally, three experiments revealed favourable immunosuppressive properties in TB-infected people with VD supplementation [27-29].

\section{Vitamin D and HIV}

Two species of retrovirus (Lentivirus subgroup) infecting human beings are human immunodeficiency viruses (HIV). Through time, they induce acquired immunodeficiency syndrome (AIDS), a disease in which the immune system's gradual failure causes opportunistic diseases and cancers that are potentially fatal to thrive [30].

VDD is a common phenomenon in patients with HIV infection. Indeed, 63 out of 97 adult patients on antiretroviral treatment were assessed to have inadequate VD rates [31-33]. The researchers 
also found that VD supplementation increased cell count regeneration over 24 weeks [31]. Moreover, a US survey of over 1700 women found that VDD occurrence among HIV+ people was 60 percent, with African American women having the highest VDD level among all ethnic groups. Likewise, a Brazilian longitudinal report of perinatally developed HIV in teenagers and young adults showed that inadequate VD incidence was 29.2\% [34,35]. A systematic study of 29 experimental VD supplement trials in HIV-infected patients found that, independent of CART, when VD intensity increased to normal limits and inflammation decreased, bone turnover indicators decreased. The threat of secondary hyperparathyroidism improved while the antibacterial responded. In 3 of 7 trials, incremental VD's improved CD4 ${ }^{+} \mathrm{T}$ cell count even though

they did not directly impact viral load because most participants were on cART [33]. Likewise, previous laboratory findings have shown that $\mathrm{VD}$ can minimize $\mathrm{CD}^{+} \mathrm{T}$ cell infection in vitro. Additional exploration is needed to determine the impact of VD supplementation on other HIVrelated diseases, including cardiovascular conditions, hypertension, or dyslipidemia. There are currently indications that VD supplementation could have an impact on people living with HIV-1, but rigorous trials are needed in order to determine the effective supplementary regimen [33].

\section{Vitamin D and fungal diseases}

Environmental-common fungi also cause fungal infections. Most fungi are not toxic, but some are very detrimental to health. Gentle fungal skin infections can appear as a rash and are normal. Lung fungal infections also mimic other diseases like flu or tuberculosis. Many fungal diseases, such as fungal meningitis and bloodstream infections, are less common than skin \& lung infections but can be lethal [36]. 
A recent laboratory evaluation tested whether VD was a contributing factor towards nephrotoxicity triggered by AMB. VD-deficient rats were found to have renal impairment consistent with elevated urinary magnesium excretion during AmB/LE care. By comparison, adequate VD animals handled with AmB/LE demonstrated natural renal function. Consequently, centred on this experimental research, it was proposed that VD could be a causative factor for AmB-induced nephrotoxicity independent of prescribed implementation [37].

\section{Vitamin D and sepsis}

Sepsis is well-known as a life-threatening illness, causing damage to the body's tissues and organs when reacting to infections. This early phase follows immune system suppression [38,39]. Infections induced by bacteria are by far the most prevalent source of sepsis, but nearly any infectious entity may be precipitated (for example, viruses, parasites, and fungi) [40]. In contrast, VD was a significant contributor since it has an analogous seasonal variability [41,42]. Observation-based findings have demonstrated a link between lower VD rates and septic threat and higher mortality $[43,44]$. Two recently published meta-analysis analyses have combined this evidence, finding a higher risk of septic sepsis in respondents with lower VD rates [45,46]. Additional experiments should be carried out before VD medication is incorporated into the therapeutic regimen for sepsis. The aspect of VD metabolite, the optimal dosage, and medication timing that will boost clinical performance in some patients with sepsis have yet to be assessed. A further task may be to normalize VD levels in chronically ill patients and most of the population with optimal VD doses to avoid septic disorder. 


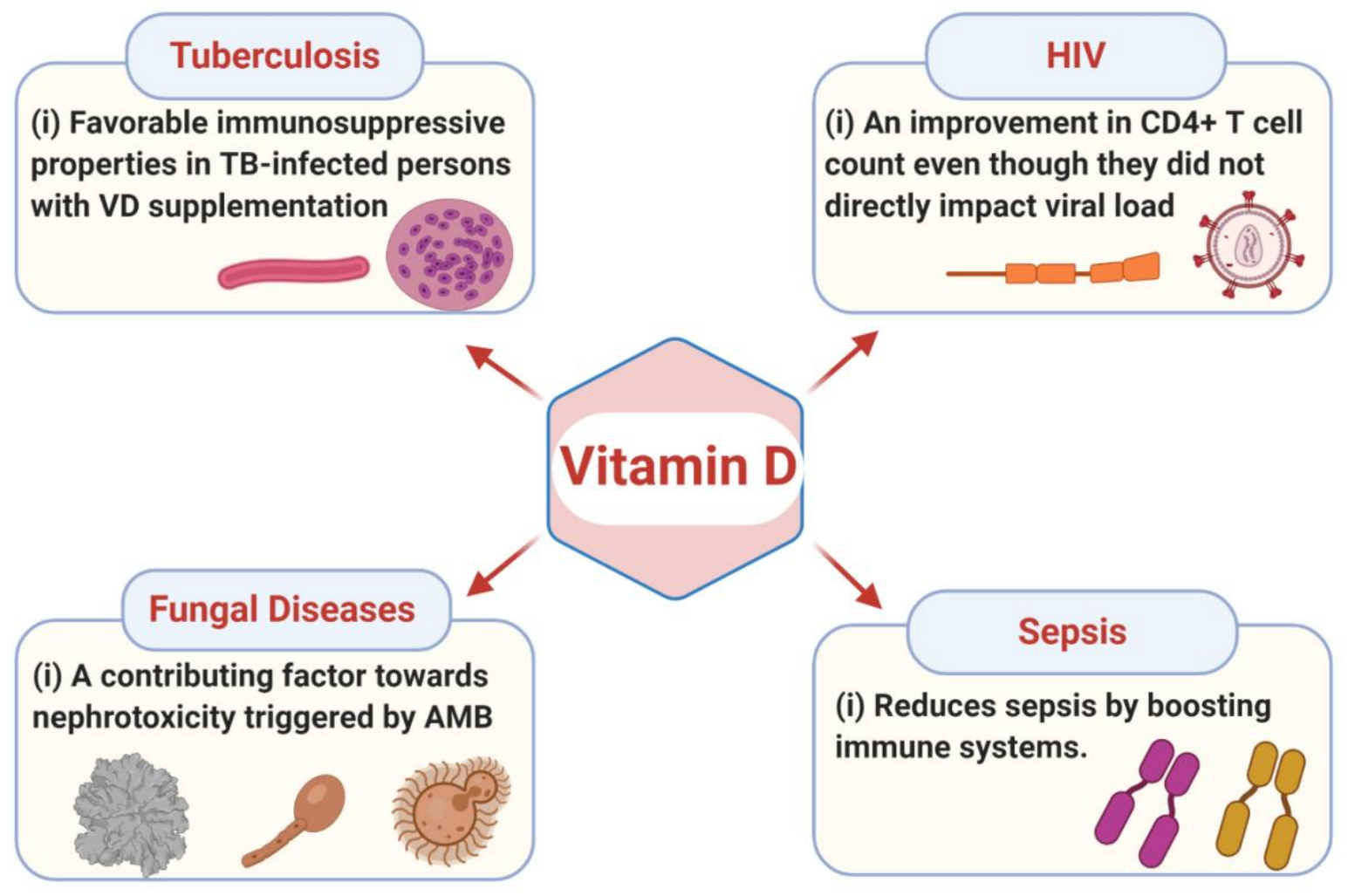

Figure 3. Role of VD in tuberculosis, HIV, fungal diseases, and sepsis

\section{Prospects of VD as a potential therapeutic agent against SARS-CoV-2 infection}

Vitamin D and innate immune response

Initially, around 30 years ago, an antimicrobial feature for 1,25 (OH)2D was addressed [47]. In investigations into the intracellular development of 1,25 $(\mathrm{OH}) 2 \mathrm{D}$, however, this antibacterial vitamin D element's importance was only evaluated later as a mechanism to promote antibacterial response to Mycobacterium tuberculosis (Mtb). On target, intracellular 1,25(OH)2D production by monocytes/macrophages facilitates the appearance and intracellular killing of Mtb in the antimicrobial protein cathelicidin [48]. The 1,25 (OH)2D vitamin D- receptor complex functions 
on VD response components of the cathelicidin gene promotor to increase cathelicidin transcription [49]. Even though cathelicidin's antimicrobial role is essential, it has a range of other activities, namely activation of a range of pro-inflammatory cytokines, stimulation of chemotaxis of monocytes, neutrophils, macrophages as well as T cells at the infection site, and advancement of clearing respiratory pathogen mediated apoptosis (a coordinated type of cell destruction in multicellular organisms) and autophagic disease of infected epithelial [50,51].

\section{T cells regulations}

Various forms of $\mathrm{T}$ cells function to defend the body from several threats. CD4+T cells furnish assistance for developing B cell antibodies and other cell forms to absorb and destroy infectious agents. T helper (Th) cell interactions are heterogeneous, while particular cytokine patterns are essential for preventing infection. Th1 cells are essential for controlling Listeria monocytogenes, M. tuberculosis, and several viral infections [52-54]. Th2 cells producing IL-4,5,13 is necessary to protect against parasitic helminths [55]. Th17 cells develop promoting factors IL-17 and -22, and granulocyte macrophage-colony (GM-CSF) and are crucial for extracellular infectious agents' tolerance $[56,57]$. The inherent natural killer $(\mathrm{NK}) \mathrm{T}$ cells are represented as other T cells. NKT cells concede lipid antigens rather than protein antigens, releasing significant numbers of cytokines early in infections. CD8+ T cells are cytotoxic T cells that kill bacterially and virally infected cells. Each of these T-cells is important for infection-protection [58]. T regulatory cells (Treg) generate IL-10 and are used to suppress effector T cell reactions in a particular antigen as well as in a nonspecific way. T reg cell dysfunction refers to an immune-mediated disorder multi-organ [59]. Therefore, T-cell response regulation is essential to boost infection removal and inflammation settlement to deter chronic T-cell activity pathology. 
VD and 1,25(OH)2D are very well defined as antagonists of $\mathrm{T}$ cells. Several studies have demonstrated the absolute and implicit effects of $1,25(\mathrm{OH}) 2 \mathrm{D}$ on T cells. Since $1983,1,25(\mathrm{OH}) 2 \mathrm{D}$ induced $\mathrm{T}$ cell proliferation and cytokine secretion following mitogenic stimulationhas been described [60,61]. In comparison, 1.25(OH)2D induced IL-2 and IFN- $\alpha$ explicitly [62,63]. Very recent evidence consistently shows $1,25(\mathrm{OH}) 2 \mathrm{D}$ inhibits IL-17 release by Th17 cells. The findings of $1,25(\mathrm{OH}) 2 \mathrm{D}$ on Th2 cells are more contentious with proof that $1,25(\mathrm{OH}) 2 \mathrm{D}$ transcriptionally suppresses IL-4 and proof that 1,25(OH)2D suppresses IL-3 in the mouse as well as human T cells [62,64-66]. The 1,25(OH)2D3 therapies mediated IL-10 and T cell growth in vitro [67]. 1,25(OH)2D also upregulated the CCR9 gut homing receptor and induced CXCR3 in T-cells that could theoretically change Th-cell homing activities. Th1 and Th17 suppressed VD and 1,25(OH)2D, mediated T reg responses, and regulated proliferation and cell position from Th [68]. The influence of 1,25(OH)2D on T reg as well as IL10 cells, which also remove Th2 responses, may describe some of the beneficial role of vitamin D in therapeutic asthma $[69,70]$. Interestingly, evidence supports that Th2 cytokines are formed by vitamin D and 1,25(OH)2D. Numerous different vitamin D targets are prone to clarify the conflicting findings of laboratory allergic asthma models in lung cells, T reg cells, and/or other immune cells.

\section{Regulation of innate and adaptive responses}

Innate and adaptive defences can be seen in several VD pathways based on various polymorphisms. Amongst the most investigated polymorphisms in the VD receptor. Through meta-analysis, the risk variability of the enveloped virus was determined by the existence of an allele identified by FokI. The bulk of the research used in this meta-analysis centred on RSV infection. Especially in comparison to $\mathrm{CT}+\mathrm{CC}$ genotypes, Fokl's recessive genotype TT increases 
sensitivity. The $\mathrm{T}$ allele decreases VD receptor complexes' potential for binding to gene components that react to VD and was frequently linked to increased susceptibility to Respiratory Syncytial Virus (RSV) infections as per this meta-analysis. The global distribution of the T allele overlaps the occurrence of RSV infection, thereby enhancing the link between VD and immune response to enveloped viruses, such as RSV [71,72].

\section{Prospects of vitamin D to Covid-19}

The leading causes underlying Covid-19 morbidity and mortality are acute respiratory disease syndrome as well as inflammatory abnormalities. Innate dysregulating immune cells, including monocytes/macrophages, neutrophils, mast cells, and cytokine storm (including IL-7, IL-2, IL-6, IP-10, G-CSF, MIP-1A, TNF $\alpha$, and MCP-1), lymphopenia and decreased functioning T cell status are both considered to play a significant role in the development and progression of the disease [73-78]. Due to the possible gain of VD, pro-inflammatory reactions in these patients tend to be decreased employing various pathways, such as selective inhibition of inflammatory cytokines, reduced leucocyte penetration to inflammatory sites, and associations with immune cells, namely monocytes/macrophages, neutrophils, and mast cells [79-82]. Besides, vitamin D can boost memory, regulatory Treg cells [78,83], decrease the proportion of neutrophils to lymphocytes [84] and affect T lymphocytes functionality [85,86]. Recently, stimulation of the C3 complement may intensify SARS-CoV-associated ARDS. In particular, C3-deficient mice contaminated with the SARS-CoV had reduced respiratory dysfunction amid similar viral pressures in the lungs, which was correlated with reduced neutrophil and inflammatory monocyte lung infiltration, as well as decreased cytokine and chemo rates, not only in the lungs but also in the sera [87].These results indicate that C3 inhibition can also reduce SRAS-CoV-2 inflammatory lung abnormalities [88]. 
VD can facilitate numerous inborn antimicrobial defences, and its antimicrobial function is primarily determined by CHDPs [79]. Several reports have established VD's antiviral role in respiratory viral infections $[89,90]$. VD in the VRR not only reduces airway inflammation but retains the antiviral state [91]. VD's precise process imposes its ability to preserve the equilibrium between reducing inflammation and strengthening the non-viral status. However, it is not entirely known [78].

While our understanding of the effect of VD on acquired immune defences remains at a first level, there is confirmation of cancer and viral infections that suggest that VD status can affect influenza by improving serological influenza vaccine counterpoint and the role of CD8+ T lymphocytes $[85,86,92]$. As this magnitude of Covid-19 is linked to lymphopenia and $\mathrm{T}$ lymphocyte dysfunction, VD may boost the role of $\mathrm{CD} 8+\mathrm{T}$ cell reactions in better SARS-COV-2 regulation, but more study has been warranted to validate these outcomes [76,93-95].

Since apoptosis and autophagy may affect a variety of facets of innate as well as adaptive immunity through a separate collection of adapters contributing to an improved host tolerance to microbial injuries, autophagy induction and apoptosis may also be a way of improving the possible benefits of VD [96]. Given the possible cross-references between autophagic coronavirus invasion and apoptotic signalling, vitamin D's function may be an essential field for prospective investigations into this area $[90,97]$.

ACE2 is demonstrated explicitly in animal models as well as in cell culture for SARS-COV-2 [98]. Attaching SARS-CoV-2 to ACE2 decreases the risk and activity of local lung angioedema via the kinin-kallikrein mechanism and extreme acute lung failure in the Covid-19 patients [99-101]. VD improved the development of ACE2, which can weaken the effect of SARS-CoV-2. As both VD and ACE2 function as destructive regulators of the renin-angiotensin system, the degree to which 
this phenomenon can benefit SARS-CoV-2 can not be shown. However, improved expression of ACE2 can also contribute to an increased risk of severe production of Covid-19 [102-105]. If so, it is enticing to assume that ACE2 may have a twofold sword function that may further threaten the potency of antiviral drugs addressing ACE2 in such patients. Contemplating SARS-CoV-2 infections as two or three stages further emphasizes the need to assess the optimum time and dose for therapeutic strategies $[101,106]$. Coronaviruses from SARS can also control the reaction of cell stress and apoptosis as seen by deleting the E gene encoding envelope protein) from SARS-CoV may improve host gene expression involving stress reaction and immunoregulation [97]. Surprisingly, vitamin D and its metabolites/analogues may also suppress endoplasmic reticulum (ER) stress and vitamin D inhibition of ER stress and oxidative stress in endothelial cells [107]. Besides, 25-OHD has been shown to inhibit macrophage adhesion and migration in type 2 diabetes by downregulating ER stress and scavenger receptor A1. These results can also apply to Covid-19 underlying disease patients [108]. 
Table 1. Current update on clinical trials (VD and Covid-19)

\begin{tabular}{|c|c|c|c|c|c|c|}
\hline Identifier No. & Study Type & $\begin{array}{l}\text { Estimated } \\
\text { Enrollment }\end{array}$ & Intervention/treatment & $\begin{array}{l}\text { Primary } \\
\text { Purpose }\end{array}$ & Phase & Ref. \\
\hline NCT04536298 & $\begin{array}{l}\text { Interventional } \\
\text { (Clinical Trial) }\end{array}$ & 2700 participants & $\begin{array}{l}\text { Dietary Supplement: Vitamin D } \\
\text { Dietary Supplement: Placebo }\end{array}$ & Treatment & Phase 3 & [109] \\
\hline NCT04385940 & $\begin{array}{l}\text { Interventional } \\
\text { (Clinical Trial) }\end{array}$ & 64 participants & $\begin{array}{l}\text { Dietary Supplement: Ddrops } \AA \text { products, } \\
50,000 \mathrm{IU} \text {, Oral } \\
\text { Dietary Supplement: Vitamin } \mathrm{D}_{3}\end{array}$ & Treatment & Phase 3 & [110] \\
\hline NCT04386044 & Observational & 1000 participants & & & & [111] \\
\hline NCT04628000 & Observational & 50 participants & & & & [112] \\
\hline NCT04407286 & $\begin{array}{l}\text { Interventional } \\
\text { (Clinical Trial) }\end{array}$ & 100 participants & Dietary Supplement: Vitamin $\mathrm{D}_{3}$ & Treatment & Phase 1 & [113] \\
\hline NCT04482673 & $\begin{array}{l}\text { Interventional } \\
\text { (Clinical Trial) }\end{array}$ & 140 participants & $\begin{array}{l}\text { Drug: Daily Vitamin } \mathrm{D}_{3} \\
\text { Drug: Daily placebo } \\
\text { Drug: Bolus vitamin } \mathrm{D}_{3} \\
\text { Drug: Bolus placebo }\end{array}$ & Prevention & Phase 4 & [114] \\
\hline
\end{tabular}




\begin{tabular}{|c|c|c|c|c|c|c|}
\hline NCT04407572 & Observational & 44 participants & $\begin{array}{l}\text { Other: Serum zinc, vitamin } \mathrm{D} \text {, vitamin } \mathrm{B}_{12} \\
\text { levels. }\end{array}$ & & & [115] \\
\hline NCT04502667 & $\begin{array}{l}\text { Interventional } \\
\text { (Clinical Trial) }\end{array}$ & 40 participants & Drug: Cholecalciferol & Treatment & Phase 3 & [116] \\
\hline NCT04535791 & $\begin{array}{l}\text { Interventional } \\
\text { (Clinical Trial) }\end{array}$ & 400 participants & Drug: Cholecalciferol & Treatment & Phase 3 & [117] \\
\hline NCT04449718 & $\begin{array}{l}\text { Interventional } \\
\text { (Clinical Trial) }\end{array}$ & 200 participants & $\begin{array}{l}\text { Dietary Supplement: Vitamin D } \\
\text { Dietary Supplement: Placebo }\end{array}$ & Treatment & N/A & [118] \\
\hline NCT04363840 & $\begin{array}{l}\text { Interventional } \\
\text { (Clinical Trial) }\end{array}$ & 1080 participants & $\begin{array}{l}\text { Drug: Aspirin } 81 \mathrm{mg} \\
\text { Dietary Supplement: Vitamin D }\end{array}$ & Treatment & Phase 2 & [119] \\
\hline NCT04370808 & Observational & 500 participants & $\begin{array}{l}\text { Other: Exposure (Individuals with SARS- } \\
\text { CoV-2 exposure and COVID-19 } \\
\text { symptoms.) }\end{array}$ & & & [120] \\
\hline NCT04483635 & $\begin{array}{l}\text { Interventional } \\
\text { (Clinical Trial) }\end{array}$ & 2414 participants & $\begin{array}{l}\text { Dietary Supplement: Placebo } \\
\text { Dietary Supplement: Vitamin D }\end{array}$ & Prevention & Phase 3 & [121] \\
\hline NCT04403932 & Observational & 500 participants & & & & {$[122]$} \\
\hline
\end{tabular}




\begin{tabular}{|c|c|c|c|c|c|c|}
\hline NCT04487951 & Observational & 100 participants & Other: Pro BNP, Vitamin D & & & [123] \\
\hline NCT04519034 & Observational & $\begin{array}{l}27000 \\
\text { participants }\end{array}$ & Other: no intervention & & & [124] \\
\hline NCT04525820 & $\begin{array}{l}\text { Interventional } \\
\text { (Clinical Trial) }\end{array}$ & 80 participants & $\begin{array}{l}\text { Drug: Single high dose vitamin D } \\
\text { Drug: Placebo } \\
\text { Drug: Treatment as usual vitamin D }\end{array}$ & Treatment & N/A & [125] \\
\hline NCT04334005 & $\begin{array}{l}\text { Interventional } \\
\text { (Clinical Trial) }\end{array}$ & 200 participants & Dietary Supplement: Vitamin D & Treatment & N/A & [126] \\
\hline NCT04394390 & $\begin{array}{l}\text { Observational } \\
\text { [Patient } \\
\text { Registry] }\end{array}$ & 100 participants & Dietary Supplement: vitamin D & & & [127] \\
\hline NCT04351490 & $\begin{array}{l}\text { Interventional } \\
\text { (Clinical Trial) }\end{array}$ & 3140 participants & $\begin{array}{l}\text { Dietary Supplement: Zinc gluconate } \\
\text { Dietary Supplement: } 25-\mathrm{OH} \\
\text { cholecalciferol }\end{array}$ & Treatment & N/A & [128] \\
\hline NCT04579640 & $\begin{array}{l}\text { Interventional } \\
\text { (Clinical Trial) }\end{array}$ & 5440 participants & Dietary Supplement: Vitamin D & Prevention & Phase 3 & [129] \\
\hline
\end{tabular}




\begin{tabular}{|c|c|c|c|c|c|c|}
\hline NCT04459247 & $\begin{array}{l}\text { Interventional } \\
\text { (Clinical Trial) }\end{array}$ & 30 participants & Drug: Vitamin D & Treatment & N/A & {$[130]$} \\
\hline NCT04335084 & $\begin{array}{l}\text { Interventional } \\
\text { (Clinical Trial) }\end{array}$ & 600 participants & $\begin{array}{l}\text { Drug: Hydroxychloroquine } \\
\text { Dietary Supplement: Vitamin C } \\
\text { Dietary Supplement: Vitamin D } \\
\text { Dietary Supplement: Zinc }\end{array}$ & Prevention & Phase 2 & [131] \\
\hline NCT04344041 & $\begin{array}{l}\text { Interventional } \\
\text { (Clinical Trial) }\end{array}$ & 260 participants & $\begin{array}{l}\text { Drug: Cholecalciferol 200,000 IU } \\
\text { Drug: Cholecalciferol 50,000 IU }\end{array}$ & Treatment & Phase 3 & [132] \\
\hline NCT04552951 & $\begin{array}{l}\text { Interventional } \\
\text { (Clinical Trial) }\end{array}$ & 80 participants & Drug: Cholecalciferol & Treatment & Phase 4 & [133] \\
\hline NCT04435119 & Observational & 96 participants & & & & [134] \\
\hline NCT04621058 & $\begin{array}{l}\text { Interventional } \\
\text { (Clinical Trial) }\end{array}$ & 108 participants & $\begin{array}{l}\text { Drug: Vitamin D } \\
\text { Drug: Placebo }\end{array}$ & Treatment & Phase 3 & {$[135]$} \\
\hline NCT04395768 & $\begin{array}{l}\text { Interventional } \\
\text { (Clinical Trial) }\end{array}$ & 200 participants & $\begin{array}{l}\text { Dietary Supplement: Vitamin C } \\
\text { Drug: Hydroxychloroquine } \\
\text { Drug: Azithromycin }\end{array}$ & Treatment & Phase 2 & [136] \\
\hline
\end{tabular}




\begin{tabular}{|c|c|c|c|c|c|c|}
\hline & & & $\begin{array}{l}\text { Dietary Supplement: Zinc Citrate } \\
\text { Dietary Supplement: Vitamin } D_{3} \\
\text { Dietary Supplement: Vitamin } B_{12}\end{array}$ & & & \\
\hline NCT04476680 & $\begin{array}{l}\text { Interventional } \\
\text { (Clinical Trial) }\end{array}$ & 4400 participants & $\begin{array}{l}\text { Dietary Supplement: Vitamin D } 1000 \text { IU } \\
\text { Drug: Placebo }\end{array}$ & Prevention & N/A & [137] \\
\hline NCT04411446 & $\begin{array}{l}\text { Interventional } \\
\text { (Clinical Trial) }\end{array}$ & 1264 participants & $\begin{array}{l}\text { Drug: Vitamin D } \\
\text { Drug: Placebo }\end{array}$ & Treatment & Phase 4 & [138] \\
\hline NCT04596657 & $\begin{array}{l}\text { Interventional } \\
\text { (Clinical Trial) }\end{array}$ & 2099 participants & $\begin{array}{l}\text { Dietary Supplement: Vitamin D } \\
\text { supplementation }\end{array}$ & Prevention & N/A & [139] \\
\hline NCT04489628 & $\begin{array}{l}\text { Interventional } \\
\text { (Clinical Trial) }\end{array}$ & 110 participants & $\begin{array}{l}\text { Drug: Vitamin } \mathrm{D}_{3} \text { or Placebo } \\
\text { Device: Doctella telehealth monitoring }\end{array}$ & Treatment & Phase 2 & [140] \\
\hline NCT04476745 & $\begin{array}{l}\text { Interventional } \\
\text { (Clinical Trial) }\end{array}$ & 100 participants & Dietary Supplement: Vitamin $\mathrm{D}_{3}$ & Prevention & N/A & [141] \\
\hline NCT04565392 & $\begin{array}{l}\text { Interventional } \\
\text { (Clinical Trial) }\end{array}$ & 216 participants & Drug: Famotidine $20 \mathrm{MG}$ & Treatment & Phase 4 & [142] \\
\hline
\end{tabular}




\begin{tabular}{|c|c|c|c|c|c|c|}
\hline NCT04609423 & $\begin{array}{l}\text { Interventional } \\
\text { (Clinical Trial) }\end{array}$ & $\begin{array}{l}80000 \\
\text { participants }\end{array}$ & $\begin{array}{l}\text { Dietary Supplement: Cod liver oil } \\
\text { Dietary Supplement: Corn oil (placebo) }\end{array}$ & Prevention & Phase 4 & [143] \\
\hline
\end{tabular}


The trial of VD and Covid-19 in 2700 U.S. men and women was randomized nationwide to study whether taking a dietary supplement of VD for four weeks lowers the likelihood of admittance and/or death of newly diagnosed Covid-19 participants as well as eliminates the threat of SARSCoV-2infection in their body clots (as validated by seroconversion) [109]. The increased frequency of VD deficiency in older people, smoking, chronically diseased patients, and excessive obesity absorption of adipose tissue allow studies into its existence as a secondary treatment agent in Covid-19 practicable. Serum 25(OH)D levels in both stationary and ambulatory Covid-19 populations should be tracked to assess the value of preserving or rising significantly the circulating concentration of $25(\mathrm{OH}) \mathrm{D}$ to the best of $100-150 \mathrm{nmol} / \mathrm{L}$ [110]. The purpose of this experiment is to perform a double-blind, randomized regulated trial on the effectiveness of VD in Covid-19 patients for three weeks in order to ascertain the association between fundamental VD deficiency and clinical features and to examine patients' responses to VD supplementation at week three and to decide their associated. Participants allocated to high-dose are advised to have 50,000 IU twice in the first week and a dose for the second and third weeks to improve their serum concentrations. Vitamin D 1000 IU will be taken by subjects in the low-dose arm for three weeks a day [110]. An observational investigation has the principal focus of determining how VD concentrations influence the outcomes of Covid-19 infection and whether the likelihood of increased VD deficiency is related [111].

In contrast, another study (observational) assessed whether patients diagnosed with VD insufficiency with Covid-19 had poorer results during their stay than those who did not have a baseline VD shortage. The main findings scrutinized include the duration of stay, additional oxygen requirements, ICU entry, intrusive life support needs (mechanical breathing, vasopressors, dialysis), and discharge status (discharged alive $v s$ death) [112]. Also, an experiment will test the 
amount of VD in Covid-19 adults. Participants with insufficient VD levels would be checked under an open-label for VD supplementation [113]. Another research seeks to determine VD intake's efficacy in mitigating the seriousness of Covid-19 symptoms and the body's inflammatory and infection-fighting reaction to Covid-19. Participants 50 years of age or over screened for Covid19 and harmful would be randomized to either normal VD (6000 IU VD $/$ day) or the standard of treatment. People of 50 or older years of age who measure Covid-19 at their baseline positively would be randomized to bolus VD (20,000 IU/day for three days) followed by a high dose $(6,000$ IU vitamin D/day) as a standard of treatment for 12 months. A multivitamin comprising VD is given to all participants [114]. This experiment measured increases in overall circulating concentration of $25(\mathrm{OH}) \mathrm{D}$, changes in the completely circulating level of $25(\mathrm{OH}) \mathrm{D}$ in Covid-19, changes in antibody titers of SARS-CoV-2, and changes in cytokine inflammatory rate [114].The information was based on another observational assessment of patients, serum Zinc, VD, and vitamin $\mathrm{B}_{12}$ concentrations of 45 patients would be assessed and evaluated in pregnant women between 18 and 45 who were diagnosed with Covid-19 positive [115]. Besides, a clinical trial is recorded as an open regulated. It demonstrated that hospitalized patients would be included in the pediatric treatment of Covid-19. Interleukins, ferritin as well as Dimer D can be determined upon admission to hospital serum. Randomization is consequently done to detect which category belongs to the patient. Regular evaluation of adverse consequences would be undertaken. Serum interleukin levels (IL)-2, 6, 7,10 would be used at the start and 7 days after admission of ferritine and dimer-D. It would be documented that the patient has a worsening respiratory system, causing endotracheal intubation and/or injection and/or death, and at what time this result would occur during the hospitalization. The analysis would be finished with the patient being released [116]. A randomized blinded experimental trial involving healthcare staff involved healthcare team 
members who take care of Covid-19 patients. There would be two categories: the VD team would take 4,000 IU orally every day for 30 days and a placebo in the control group during the same period. After 45 days, new samples of VD and antibodies to SARS-CoV-2 will be taken [117]. Indeed, an interventional double-blind study outlined among 240 participants documented that VD supplementation may have beneficial implications for Covid-19 patients [118].

Owing to the overlapping population, regional, pathological, and therapeutic consequences of extreme Covid-19 as well as VD insufficiency (VDI), investigators believe that VDI is a significant contributor to CAC. This theory is backed by partial evidence from seriously ill Covid-19 patients in New Orleans. Besides, VDI models established exacerbated multi-organ thrombus production following lipopolysaccharide injection, the CAC similar phenotype. The goal of the anticipated randomized clinical trial is to assess the theory of low-risk early aspirin and VD therapy with Covid-19 to minimize and decrease hospitalization frequency [119]. Findings from China, as well as Italy, indicate hypertension poses an elevated threat to Covid-19 mortality. Otherwise, observational results demonstrate that $25(\mathrm{OH}) \mathrm{D}$ causes respiratory pathogens to be covered, whereas broader studies show serum $25(\mathrm{OH}) \mathrm{D}$ is inversely linked to hypertension. The latest statistics suggest that $66 \%$ of Portuguese adults have vitamin D insufficiency.

The genetic database of Heart-Genetics reveals that in this population, the incidence of Vitamin D polymorphism is four times greater than the EU norm, which raises the risk of hypovitaminosis D. In comparison, Covid-19 patients possess a significant hypovitaminosis D incidence. Investigators strive to determine whether genetics in VD-related genes, particularly in hypertension and CV patients, lead to the bad Covid-19 result, suggesting customized therapies focused on VD supplementation to minimize severity and death [120]. A 16-week placebo-controlled parallelgroup, triple-blind, randomized vitamin D supplementation trial relative to placebo in health care 
employees. In this assessment, all randomized participants would be analyzed for intention-totreat. Prevalence and protection analysis would be conducted under allocation camouflage with unblinding after trial termination and preliminary result review [121]. In an observational investigation $(\mathrm{n}=500)$, the significant impact was a composite of death, referral to the intensive care unit (ICU), and/or a more significant oxygen supply requirement than the nasal cannula. The primary relationship between VD - clustering - and the principal finding would be tested using univariate analysis and multivariable logistic regression using the following preset confounders: gender, age, obesity, and chronic kidney disease (CKD) [122]. Also, another observational study of 100 participants (case-control, cross-sectional) was executed. This investigation's key findings are intended to determine the disparity between NT-pro-BNP levels and VD in mild cases that advanced to serious or critically ill groups relative to those that did not. The secondary objective is to determine any potential association between NT-pro-BNP and VD and the necessity for mechanical ventilation or death in Covid-19 [123].

In contrast, another observational study $(\mathrm{n}=27000)$ mainly aimed to include a snapshot of VD levels by sex, age, ethnicity, and BMI in patients from the South-East London area and showed ethnic variations in VD levels as well as correlations with severe $v s$ mild Covid-19 infections. The secondary target is to establish the relationship between VD levels and different cytokines (proinflammatory molecules) as well as disease seriousness [124]. Using VD as an influenza prophylactic has demonstrated potential for avoiding disease and reducing secondary asthma in infants. Insufficient VD levels are linked to upper respiratory infections (URI) in individuals with chronic obstructive pulmonary disease (COPD). ViDiCo-trial VD supplementation shielded against mild to severe exacerbation but not URI in COPD patients. 
Further research retrospectively analyzed results from 108 patients with acute respiratory distress syndrome (ARDS) for whom VD level was accessible at diagnosis and showed that more than 95\% of these patients had VD deficiencies. A strong inverse association between serum 25hydroxyvitamin D and hospital length of stay among survivors was found when tested according to serum 25-hydroxyvitamin D quarterly. Consequently, VD replacement in Covid-19 patients with VD insufficiency should be tested for effectiveness and protection. For this reason, the investigators conducted a randomized, placebo-controlled double-blind study to assess the hypothesis that a single elevated dose of vitamin D in addition to standard therapy increases the healing time in patients with Covid-19 and VD insufficiency only relative to standard care. That implies the healing period is only shorter in the single high-dose VD group compared to the normal treatment group [125].

Furthermore, in the background, decreased VD levels in calves were the primarybovine coronavirus infection source. Therefore, it appears possible that VD's use as dietary ergogenic support may be a potential strategy to combat patients afflicted with Covid-19 who are asymptomatic or have non-serious and severe symptoms. This research aimed to examine whether the utilization of VD as an immune modulator causes substantial changes in the health status and results of non-serious symptomatic individuals infected with Covid-19 and avoids degradation of Covid-19. Investigators presume that VD would significantly boost harsh endpoints linked to Covid-19 deleterious effects relative to an average community of treatment monitors [126]. Some patients with extreme Covid-19 undergo a cytokine storm to release vast amounts of interleukins, especially IL-1 and -6. It was also hypothesized that adequate VD levels could help reduce levels of IL-6, such as tocizulamab, a powerful blocking element of the IL-6 receptor. In the current trial, investigators tried to determine a link between the rates of disease and VD in patients with Covid- 
19 [127]. Covid-19 mortality rises with age, hitting $14.8 \%$ at age 80 . The seriousness of the infection is consistent with ARDS, which needs intensive care. ARDS is the result of an inflammatory storm destroying the lungs. Ages are especially vulnerable to deficiencies of zinc and VD. These two micronutrients can modulate the immune response by decreasing the storm. The assumption is that zinc and VD supplementation would lessen the inflammatory reaction that aggravates ARDS, leading to the death of Covid-19 contaminated subjects [128].

In contrast, an interventional open-label, phase 3 , randomized clinical trial $(n=5440)$ investigating whether adopting a sub-optimal VD correction strategy results in diminished risk and/or incidence of Covid-19 as well as other acute respiratory infections [129]. Prior SARS-CoV-2 negativity may have notable public health advantages in reducing disease spread. Consequently, investigators assume that high-dose VD supplementation in Covid-19 and VD imbalance patients may lead to SARS-CoV-2 negativity in higher densities of patients associated with decreased serological inflammation indicators [130]. Also, another phase II interventional study investigating whether hydroxychloroquine, vit-C, VD, and zinc would mitigate Covid-19 symptoms [131]. High-dose oral $\mathrm{VD}_{3}$ supplementation was described as reducing short-term death rates in patients with extreme hypovitaminosis D (17 percent absolute risk depletion) (17 percent absolute risk reduction). Taking oral VD supplementation at doses up to 10,000 IU/day is considered safe for limited intervals, especially in older adults, i.e., a population that is mainly influenced by hypovitaminosis D and should consume 1,500 IU of VD daily to ensure adequate VD status. VD supplementation is a highly promising treatment for SARS-CoV-2 infection, but on a clinical basis with inadequate evidence to date. High-dose VD supplementation is hypothesized to strengthen the prognosis of elderly patients hospitalized with Covid-19 compared to regular VD [132]. Also, an interventional trial $(\mathrm{n}=80)$ demonstrated that a single dose of 100,000 cholecalciferol IU (VD 
Arm) or no VD was randomized in patients diagnosed with Covid-19. The health, biochemical, and radiological findings and mortality were analyzed for the Covid-19 illness [133]. In French nursing homes, all patients are routinely and consistently supplied with bolus $\mathrm{VD}_{3}$ (every single, 2 , or 3 months, depending on residents). The experiment's key focus is to evaluate whether bolus $\mathrm{VD}_{3}$ supplementation taken before or during the month before Covid-19 has successfully enhanced the longevity of vulnerable, Covid-19 affected nursing homes compared with those that have been supplemented longer. The secondary goal is to assess if the supplementation of bolus $\mathrm{VD}_{3}$ taken during or during the month before Covid-19 is successful in reducing the clinical seriousness of the infection according to the Ordinal Scale for Clinical Improvement (OSCI) of the World Health Organization for Covid-19 compared with those obtained earlier [134].

Moreover, administration of VD supplementation to patients with a stable diagnosis of SARS$\mathrm{CoV}-2$, acute pneumonia triggering hospital admission as well as VD inadequacy is more beneficial than those lacking VD (placebo). This beneficial evolution would result in decreased deaths, fewer ICU admissions, and reduced hospital stay days. Therefore, investigators executed an interventional trial $(\mathrm{n}=108)$ to determine whether the team of patients taking VD supplementation had a less severe evolution of their acute pneumonia, which converted into reduced death rates than patients not receiving this supplement [135]. The use of hydroxychloroquine, azithromycin, and zinc have demonstrated promising effects in various parts of the world, and early trials of some of these, alongside some with vit-C, have also proved useful. VD rates have also been found to reflect the seriousness of symptoms in Covid-19 patients [136]. Besides, an interventional trial was executed to show a decrease in 'silent' seroconversion rates associated with the decreased asymptomatic transmission of SARS-CoV-2 in a young and healthy adult population after 24 weeks of oral VD aided at 1000 I.U. Regular versus placebo-matching. 
This would implement a double-blind, randomized design contrasting supplementation with 1000 IU regular VD and placebo in adults aged 18-30. Participants will be selected to align with the launch of the autumn term. In compliance with the power estimation and expected drop-out rate, the intervention (vitamin D) arm would enrol 2200 volunteers and the placebo arm 2200. Baseline and 3-weekly data obtained during the rest of the study will include seroconversion conditions assessed using a standardized Dried Blood Spot (DBS) approach combined with new salivary antibody monitoring and organized questionnaire answers screening for Covid-19 symptoms. Physical and demographic attributes and serum rates of VD concentrations obtained from research entry participants will promote secondary goals in investigating the impact of gender, race, body mass, and BMIon asymptomatic seroconversion and VD level interactions supplementation [137]. A phase 4 interventional randomized trial $(n=1264)$ conducted the study hypothesis that increased VD levels administered orally to patients admitted to Covid-19 would reduce respiratory derivation and other clinical severe events. The randomized-controlled, double-blind trial measuring a 500,000 UI dose of VD versus placebo in Covid-19 patients at mild risk was planned to test the hypothesis mentioned above, involving hospitalization but without critical care at admission. The intervention is one dosage of 500,000 UI offered orally or as a placebo. Both research findings would be assessed during hospitalization [138]. In contrast, another interventional investigation into the $\mathrm{VD}_{3}$ study is a longitudinal study testing whether regular $\mathrm{VD}_{3}$ supplementation in healthcare employees can reduce respiratory tract infections [139]. Also, an interventionaltrial $(\mathrm{n}=110)$ was implemented to determine the effectiveness of high-dose VD (an over-the-counter dietary supplement) in avoiding immune problems in outpatients with reported SARS-CoV-2 infection [140]. 
Additionally, an interventional trial between 100 participants (both male and female, age $\geq 30$ years) aims to determine whether increased doses of $\mathrm{VD}_{3}$ in uninfected Jordanian people would enhance immune responses to Covid-19 infection. Investigators assumed that weekly 50,000 I.U. $\mathrm{VD}_{3}$ supplementation would substantially improve immune responses relative to the control group [141]. In contrast, a phase 4 randomized clinical trial $(n=216)$ was executed. Those with early Covid-19 signs took 1 or $220 \mathrm{mg}$ tabs/day of famotidine (famotidine $20 \mathrm{mg}$ ) with 2000 IU VD3 and 2 grams (2000 mg) of vit-C for 14 days. Authorization,baseline, and post-treatment follow-up weredone online. A 14-day higher dose extension with vitamins is permitted. Results on 216 subjects give $80 \%$ control at $\mathrm{p}=0.05$ if $22 \%$ get hospitalized with low-dose vs. $7 \%$ with "high"dose famotidine [142]. Also, a parallel-group treatment, randomized, two-arm, quadruple masked trial was accomplished to determine the efficacy of cod liver oil in preventing Covid-19 and respiratory infections in healthy adults. Researchers will examine whether regular cod liver oil would avoid Covid-19 infections and decrease such infections' seriousness in this analysis. Investigators will also investigate whether cod liver oil eliminates other airway infections [143].

\section{Conclusion and perspectives}

The dynamic connection between SARS-CoV-2 and the privileges of VD is still a fascinating phenomenon. Given the significant increases in underlying VD rates in the general population and the knowledge that the significant improvements are focused primarily on serum 25-OHD concentrations, serum 1,25(OH) 2D calculation, and circulating protein binding VD levels together with genotyping VD-related genes will be more evident in Covid-19. A thorough understanding of VD's biological activities and the potential risk factors will provide more understanding of disease pathogenesis in Covid-19 cases. Considering that VD level is manipulated by various 
genetic and environmental factors, such as genetic polymorphisms, the form of skin (pigmentation), age, the conduct of sunshine, season, obesity, latitude, and diet, well-designed findings with inclusion or exclusion criteria are vital to our interpretation of the precise function of VD supplementation in Covid-19 [144].

\section{Acknowledgement}

The authors would like to thank the Laboratory of Computational Biosciences (LBC), Gopalganj 8100, Bangladesh, for supporting this study.

\section{Conflict of interest}

There is no conflict of interest to declare.

\section{References}

[1] Zhu N, Zhang D, Wang W, Li X, Yang B, Song J, et al. A novel coronavirus from patients with pneumonia in China, 2019. N Engl J Med 2020;382:727-33. https://doi.org/10.1056/NEJMoa2001017.

[2] Zhou M, Zhang X, Qu J. Coronavirus disease 2019 (COVID-19): a clinical update. Front Med 2020;14:126-35. https://doi.org/10.1007/s11684-020-0767-8.

[3] Zhou G, Chen S, Chen Z. Advances in COVID-19: the virus, the pathogenesis, and evidence-based control and therapeutic strategies. Front Med 2020;14:117-25. https://doi.org/10.1007/s11684-020-0773-X. 
[4] Chen N, Zhou M, Dong X, Qu J, Gong F, Han Y, et al. Epidemiological and clinical characteristics of 99 cases of 2019 novel coronavirus pneumonia in Wuhan, China: a descriptive study. Lancet 2020;395:507-13. https://doi.org/10.1016/S0140-6736(20)30211-7.

[5] Wu C, Liu Y, Yang Y, Zhang P, Zhong W, Wang Y, Wang Q, Xu Y, Li M, Li X, Zheng M, Chen L LH. Analysis of therapeutic targets for SARS-CoV-2 and discovery of potential drugs by computational methods. Acta Pharm Sin B 2020;May:766-88. https://doi.org/10.1016/j.apsb.2020.02.008.

[6] Mandelbaum RF. Scientists Create Atomic-Level Image of the New Coronavirus's Potential Achilles Heel 2020. https://gizmodo.com/scientists-create-atomic-level-image-of-thenew-coronav-1841795715 (accessed November 21, 2020).

[7] Aronson JK. Coronaviruses - a general introduction 2020. https://www.cebm.net/covid19/coronaviruses-a-general-introduction/ (accessed November 21, 2020).

[8] McCartney DM, Byrne DG. Optimisation of vitamin d status for enhanced immunoprotection against covid-19. Ir Med J 2020;113:20-3.

[9] Prietl B, Treiber G, Pieber TR, Amrein K. Vitamin D and immune function. Nutrients 2013;5:2502-21. https://doi.org/10.3390/nu5072502.

[10] Camargo CA, Ganmaa D, Frazier AL, Kirchberg FF, Stuart JJ, Kleinman K, et al. Randomized trial of vitamin D supplementation and risk of acute respiratory infection in Mongolia. Pediatrics 2012;130:113-5. https://doi.org/10.1542/peds.2011-3029.

[11] Panarese A, Shahini E. Letter: Covid-19, and vitamin D. Aliment Pharmacol Ther 2020;51:993-5. https://doi.org/10.1111/apt.15752. 
[12] Alipio M. Vitamin D Supplementation Could Possibly Improve Clinical Outcomes of Patients Infected with Coronavirus-2019 (COVID-2019). SSRN Electron J 2020;2019:1-9. https://doi.org/10.2139/ssrn.3571484.

[13] Grant WB, Lahore H, McDonnell SL, Baggerly CA, French CB, Aliano JL, et al. Evidence that vitamin d supplementation could reduce risk of influenza and covid-19 infections and deaths. Nutrients 2020;12:1-19. https://doi.org/10.3390/nu12040988.

[14] National Institutes of Health (NIH). Vitamin D. Strength Knowl Underst Diet Suppl 2020. https://ods.od.nih.gov/factsheets/VitaminD-HealthProfessional/ (accessed November 8, 2020).

[15] British Dietetic Association (BDA). Vitamin D: Food Fact Sheet 2020. https://www.bda.uk.com/resource/vitamin-d.html (accessed November 8, 2020).

[16] DeLuca HF. History of the discovery of vitamin D and its active metabolites. Bonekey Rep 2014;3:1-8. https://doi.org/10.1038/bonekey.2013.213.

[17] Holick MF, Frommer JE, McNeill SC, Richtand NM, Henley JW, Potts JT. Photometabolism of 7-dehydrocholesterol to previtamin D3 in skin. Biochem Biophys Res Commun 1977;7:541-59.

[18] Rasool SI, De Bergh C. Unique biosynthesis by kidney of a biological active vitamin D metabolite. Nat Publ Gr 1970;228:726-34.

[19] Norman, A W. From vitamin D to hormone D: Fundamentals of vitamin D endocrine system essential for good health. Am J Clin Nutr 2008;88:491S-499S.

[20] Dusso AS, Brown AJ, Slatopolsky E. Vitamin D. Am J Physiol - Ren Physiol 2005;289:828. https://doi.org/10.1152/ajprenal.00336.2004. 
[21] WHO. Tuberculosis 2020. https://www.who.int/news-room/fact-sheets/detail/tuberculosis (accessed November 13, 2020).

[22] WHO. How many TB cases and deaths are there? 2020. https://www.who.int/gho/tb/epidemic/cases_deaths/en/ (accessed November 13, 2020).

$\begin{array}{lllll}\text { [23] WHO. Global } & \text { tuberculosis } & \text { report } & 2020 & 2020 .\end{array}$ https://www.who.int/tb/publications/global report/en/ (accessed November 13, 2020).

[24] Martineau AR, Honecker FU, Wilkinson RJ, Griffiths CJ. Vitamin D in the treatment of pulmonary tuberculosis. J Steroid Biochem Mol Biol 2007;103:793-8. https://doi.org/10.1016/j.jsbmb.2006.12.052.

[25] Williams CJB. On The Use and Administration Of Cod-Liver Oil in Pulmonary Consumption. Lond J Med 1849;s2-1:1-18. https://doi.org/10.1136/bmj.s2-1.1.1.

[26] Martineau AR, Timms PM, Bothamley GH, Hanifa Y, Islam K, Claxton AP, et al. Highdose vitamin D3 during intensive-phase antimicrobial treatment of pulmonary tuberculosis: A double-blind randomised controlled trial. Lancet 2011;377:242-50. https://doi.org/10.1016/S0140-6736(10)61889-2.

[27] Salahuddin N, Ali F, Hasan Z, Rao N, Aqeel M, Mahmood F. Vitamin D accelerates clinical recovery from tuberculosis: Results of the SUCCINCT Study [Supplementary Cholecalciferol in recovery from tuberculosis]. A randomized, placebo-controlled, clinical trial of vitamin D supplementation in patients with pulmonar. BMC Infect Dis 2013;13:1-11. https://doi.org/10.1186/1471-2334-13-22. 
[28] Mily A, Rekha RS, Kamal SMM, Arifuzzaman ASM, Rahim Z, Khan L, et al. Significant effects of oral phenylbutyrate and Vitamin D3 adjunctive therapy in pulmonary tuberculosis: A randomized controlled trial. PLoS One 2015;10:1-25. https://doi.org/10.1371/journal.pone.0138340.

[29] Coussens AK, Wilkinson RJ, Hanifa Y, Nikolayevskyy V, Elkington PT, Islam K, et al. Vitamin D accelerates resolution of inflammatory responses during tuberculosis treatment. Proc Natl Acad Sci U S A 2012;109:15449-54. https://doi.org/10.1073/pnas.1200072109.

[30] Douek DC, Roederer M, Koup RA. Emerging concepts in the immunopathogenesis of AIDS. Annu Rev Med 2009;60:471-84. https://doi.org/10.1146/annurev.med.60.041807.123549.

[31] Coelho L, Cardoso SW, Luz PM, Hoffman RM, Mendonça L, Veloso VG, et al. Vitamin D3 supplementation in HIV infection: effectiveness and associations with antiretroviral therapy. Nutr J 2015;14:1-9. https://doi.org/10.1186/s12937-015-0072-6.

[32] Griffin AT, Arnold FW. Review of metabolic, immunologic, and virologic consequences of suboptimal vitamin D levels in HIV infection. AIDS Patient Care STDS 2012;26:516-25. https://doi.org/10.1089/apc.2012.0145.

[33] Alvarez N, Aguilar-Jimenez W, Rugeles MT. The potential protective role of vitamin D supplementation on HIV-1 infection. Front Immunol 2019;10. https://doi.org/10.3389/fimmu.2019.02291.

[34] Chotalia J, Frontini M, Tatini P, Nsuami MJ, Martin DH, Clark RA. Vitamin D deficiency in HIV-infected and -uninfected women in the united states. J Acquir Immune Defic Syndr 2012;59:197-204. https://doi.org/10.1097/QAI.0b013e31824a0d1d. 
[35] Schtscherbyna A, Gouveia C, Pinheiro MFMC, Luiz RR, Farias MLF, Machado ES. Vitamin D status in a brazilian cohort of adolescents and young adults with perinatally acquired human immunodeficiency virus infection. Mem Inst Oswaldo Cruz 2016;111:127-33. https://doi.org/10.1590/0074-02760150403.

[36] CDC. Fungal Diseases 2020. https://www.cdc.gov/fungal/index.html (accessed November $14,2020)$.

[37] Gois PHF, Ferreira D, Olenski S, Seguro AC. Vitamin D and infectious diseases: Simple bystander or contributing factor? Nutrients 2017;9:1-19. https://doi.org/10.3390/nu9070651.

[38] Singer M, Deutschman CS, Seymour C, Shankar-Hari M, Annane D, Bauer M, et al. The third international consensus definitions for sepsis and septic shock (sepsis-3). JAMA - J Am Med Assoc 2016;315:801-10. https://doi.org/10.1001/jama.2016.0287.

[39] Cao C, Yu M, Chai Y. Pathological alteration and therapeutic implications of sepsisinduced immune cell apoptosis. Cell Death Dis 2019;10:1-14. https://doi.org/10.1038/s41419019-2015-1.

[40] Remick DG. Pathophysiology of sepsis. Am J Pathol 2007;170:1435-44. https://doi.org/10.2353/ajpath.2007.060872.

[41] Klingberg E, Oleröd G, Konar J, Petzold M, Hammarsten O. Seasonal variations in serum 25-hydroxy vitamin D levels in a Swedish cohort. Endocrine 2015;49:800-8. https://doi.org/10.1007/s12020-015-0548-3. 
[42] Danai PA, Sinha S, Moss M, Haber MJ, Martin GS. Seasonal variation in the epidemiology of sepsis. Crit Care Med 2007;35:410-5. https://doi.org/10.1097/01.CCM.0000253405.17038.43.

[43] Braun AB, Gibbons FK, Litonjua AA, Giovannucci E, Christopher KB. Low serum 25hydroxyvitamin D at critical care initiation is associated with increased mortality. Crit Care Med 2012;40:63-72. https://doi.org/10.1097/CCM.0b013e31822d74f3.

[44] Moromizato T, Litonjua AA, Braun AB, Gibbons FK, Giovannucci E, Christopher KB. Association of low serum 25-hydroxyvitamin D levels and sepsis in the critically ill. Crit Care Med 2014;42:97-107. https://doi.org/10.1097/CCM.0b013e31829eb7af.

[45] Upala S, Sanguankeo A, Permpalung N. Significant association between vitamin D deficiency and sepsis: A systematic review and meta-analysis. BMC Anesthesiol 2015;15. https://doi.org/10.1186/s12871-015-0063-3.

[46] de Haan K, Groeneveld JBJ, de Geus HRH, Egal M, Struijs A. Vitamin D deficiency as a risk factor for infection, sepsis and mortality in the critically ill: Systematic review and metaanalysis. Crit Care 2014;18:1-8. https://doi.org/10.1186/s13054-014-0660-4.

[47] Rook GA, Steele J, Fraher L, Barker S, Karmali R, O’Riordan J, et al. Vitamin D3, gamma interferon, and control of proliferation of Mycobacterium tuberculosis by human monocytes. Immunology 1986;57:159-63.

[48] Martin L, Garrity DM, Yao T. Genomics and transcriptomics of the molting gland (Yorgan) in the blackback land crab, Gecarcinus lateralis. Colorado State University. Libraries; 2016. 
[49] Wang T-T, Nestel FP, Bourdeau V, Nagai Y, Wang Q, Liao J, et al. Cutting Edge: 1,25Dihydroxyvitamin D 3 Is a Direct Inducer of Antimicrobial Peptide Gene Expression . J Immunol 2004;173:2909-12. https://doi.org/10.4049/jimmunol.173.5.2909.

[50] Yuk JM, Shin DM, Lee HM, Yang CS, Jin HS, Kim KK, et al. Vitamin D3 Induces Autophagy in Human Monocytes/Macrophages via Cathelicidin. Cell Host Microbe 2009;6:23143. https://doi.org/10.1016/j.chom.2009.08.004.

[51] Greiller CL, Martineau AR. Modulation of the immune response to respiratory viruses by vitamin D. Nutrients 2015;7:4240-70. https://doi.org/10.3390/nu7064240.

[52] Haanen JBAG, de Waal Malefijt R, Res PCM, Kraakman EM, Ottenhof THM, de Vries RRP, et al. Selection of a human T helper type 1-like T cell subset by mycobacteria. J Exp Med 1991;174:583-92. https://doi.org/10.1084/jem.174.3.583.

[53] Hsieh C, Macatonia SE, Tripp CS, Wolf SF, Garra AO, Murphy KM. Pillars Article : Development of T H 1 CD4 + T Cells Through IL-12 Produced by Listeria. J Immunol 2013;181:4437-9.

[54] Swain SL, McKinstry KK, Strutt TM. Expanding roles for CD4 + T cells in immunity to viruses. Nat Rev Immunol 2012;12:136-48. https://doi.org/10.1038/nri3152.

[55] Maizels RM, Hewitson JP, Smith KA. Susceptibility and immunity to helminth parasites. Curr Opin Immunol 2012;24:459-66. https://doi.org/10.1016/j.coi.2012.06.003. 
[56] Ishigame H, Kakuta S, Nagai T, Kadoki M, Nambu A, Komiyama Y, et al. Differential Roles of Interleukin-17A and -17F in Host Defense against Mucoepithelial Bacterial Infection and Allergic Responses. Immunity 2009;30:108-19. https://doi.org/10.1016/j.immuni.2008.11.009.

[57] Weaver CT, Elson CO, Fouser LA, Kolls JK. The Th17 pathway and inflammatory diseases of the intestines, lungs, and skin. Annu Rev Pathol Mech Dis 2013;8:477-512. https://doi.org/10.1146/annurev-pathol-011110-130318.

[58] Matsuda JL, Mallevaey T, Scott-Browne J, Gapin L. CD1d-restricted iNKT cells, the "Swiss-Army knife" of the immune system. Curr Opin Immunol 2008;20:358-68. https://doi.org/10.1016/j.coi.2008.03.018.

[59] Gratz IK, Campbell DJ. Organ-specific and memory Treg cells: Specificity, development, function, and maintenance. Front 2014;5:1-17. https://doi.org/10.3389/fimmu.2014.00333.

[60] Provvedini, Diego M., Constantine D. Tsoukas, Leonard J. Deftos and SCM. 1, 25dihydroxyvitamin D3 receptors in human leukocytes. Science (80- ) 1983;221:1181-3.

[61] Rigby WFC, Stacy T, Fanger MW. Inhibition of T lymphocyte mitogenesis by 1,25dihydroxyvitamin $\quad$ D3 (calcitriol). J Clin Invest 1984;74:1451-5. https://doi.org/10.1172/JCI111557.

[62] Boonstra A, Barrat FJ, Crain C, Heath VL, Savelkoul HFJ, O’Garra A. 1 1, 25 Dihydroxyvitamin D3 Has a Direct Effect on Naïve CD4 + T Cells to Enhance the Development of Th2 Cells . J Immunol 2001;167:4974-80. https://doi.org/10.4049/jimmunol.167.9.4974. 
[63] Palmer MT, Lee YK, Maynard CL, Oliver JR, Bikle DD, Jetten AM, et al. Lineage-specific effects of 1,25-dihydroxyvitamin D3 on the development of effector CD4 T cells. J Biol Chem 2011;286:997-1004. https://doi.org/10.1074/jbc.M110.163790.

[64] Staeva-Vieira TP, Freedman LP. 1,25-Dihydroxyvitamin D 3 Inhibits IFN- $\gamma$ and IL-4 Levels During In Vitro Polarization of Primary Murine CD4 $+\mathrm{T}$ Cells . J Immunol 2002;168:1181-9. https://doi.org/10.4049/jimmunol.168.3.1181.

[65] Mahon BD, Wittke A, Weaver V, Cantorna MT. The targets of vitamin D depend on the differentiation and activation status of CD4 positive T cells. J Cell Biochem 2003;89:922-32. https://doi.org/10.1002/jcb.10580.

[66] Pichler J, Gerstmayr M, Szépfalusi Z, Urbanek R, Peterlik M, Willheim M. 1 1,25(OH)2D3 inhibits not only Th1 but also Th2 differentiation in human cord blood T cells. Pediatr Res 2002;52:12-8. https://doi.org/10.1203/01.PDR.0000017267.23950.48.

[67] Korf H, Wenes M, Stijlemans B, Takiishi T, Robert S, Miani M, et al. 1,25Dihydroxyvitamin D3 curtails the inflammatory and T cell stimulatory capacity of macrophages through an IL-10-dependent mechanism. Immunobiology 2012;217:1292-300. https://doi.org/10.1016/j.imbio.2012.07.018.

[68] Sigmundsdottir H, Pan J, Debes GF, Alt C, Habtezion A, Soler D, et al. DCs metabolize sunlight-induced vitamin D3 to "program" T cell attraction to the epidermal chemokine CCL27. Nat Immunol 2007;8:285-93. https://doi.org/10.1038/ni1433. 


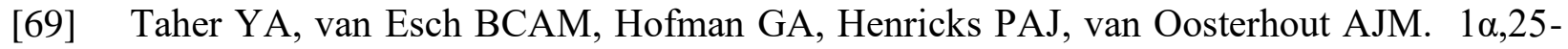
Dihydroxyvitamin D 3 Potentiates the Beneficial Effects of Allergen Immunotherapy in a Mouse Model of Allergic Asthma: Role for IL-10 and TGF- $\beta$. J Immunol 2008;180:5211-21. https://doi.org/10.4049/jimmunol.180.8.5211.

[70] Gorman S, Judge MA, Burchell JT, Turner DJ, Hart PH. 1,25-dihydroxyvitamin D3 enhances the ability of transferred CD4+ CD25+ cells to modulate T helper type 2-driven asthmatic responses. Immunology 2010;130:181-92. https://doi.org/10.1111/j.13652567.2009.03222.x.

[71] Rudensky AY. Regulatory T cells and Foxp3. Immunol Rev 2011;241:260-8. https://doi.org/10.1111/j.1600-065X.2011.01018.x.

[72] Li X, Zheng Y. Regulatory T cell identity: Formation and maintenance. Trends Immunol 2015;36:344-53. https://doi.org/10.1016/j.it.2015.04.006.

[73] Huang C, Wang Y, Li X, Ren L, Zhao J, Hu Y, et al. Clinical features of patients infected with 2019 novel coronavirus in Wuhan, China. Lancet 2020;395:497-506. https://doi.org/10.1016/S0140-6736(20)30183-5.

[74] Theoharides TC. COVID-19, pulmonary mast cells, cytokine storms, and beneficial actions of luteolin. BioFactors 2020;46:306-8. https://doi.org/10.1002/biof.1633.

[75] Teymoori-Rad M, Samadizadeh S, Tabarraei A, Moradi A, Shahbaz MB, Tahamtan A. Ten challenging questions about SARS-CoV-2 and COVID-19. Expert Rev Respir Med 2020;14:8818. https://doi.org/10.1080/17476348.2020.1782197. 
[76] Cao X. COVID-19: immunopathology and its implications for therapy. Nat Rev Immunol 2020;20:269-70. https://doi.org/10.1038/s41577-020-0308-3.

[77] Prompetchara E, Ketloy C, Palaga T. Immune responses in COVID-19 and potential vaccines: Lessons learned from SARS and MERS epidemic. Asian Pacific J Allergy Immunol 2020;38:1-9. https://doi.org/10.12932/AP-200220-0772.

[78] Schett G, Sticherling M, Neurath MF. COVID-19: risk for cytokine targeting in chronic inflammatory diseases? Nat Rev Immunol 2020;20:271-2. https://doi.org/10.1038/s41577-020$\underline{0312-7 .}$

[79] Teymoori-Rad M, Shokri F, Salimi V, Marashi SM. The interplay between vitamin D and viral infections. Rev Med Virol 2019;29:1-16. https://doi.org/10.1002/rmv.2032.

[80] XU H, SORURI A, GIESELER RKH, PETERS JH. 1,25-Dihydroxyvitamin D3 Exerts Opposing Effects to IL-4 on MHC Class-II Antigen Expression, Accessory Activity, and Phagocytosis of Human Monocytes. Scand J Immunol 1993;38:535-40. https://doi.org/10.1111/j.1365-3083.1993.tb03237.x.

[81] Hirsch D, Archer FE, Joshi-Kale M, Vetrano AM, Weinberger B. Decreased antiinflammatory responses to vitamin D in neonatal neutrophils. Mediators Inflamm 2011;2011:1-8. https://doi.org/10.1155/2011/598345.

[82] Yip K-H, Kolesnikoff N, Yu C, Hauschild N. Vitamin D3 represses IgE-dependent mast cell activation via mast cell-CYP27B1 and -vitamin D receptor activity. J Allergy Clin Immunol 2014;133:1-23. https://doi.org/10.1016/j.jaci.2013.11.030.Vitamin. 
[83] Baeke F, Takiishi T, Korf H, Gysemans C, Mathieu C. Vitamin D: Modulator of the immune $\quad$ system. Curr Opin 2010;10:482-96. https://doi.org/10.1016/j.coph.2010.04.001.

[84] Tabatabaeizadeh SA, Avan A, Bahrami A, Khodashenas E, Esmaeili H, Ferns GA, et al. High Dose Supplementation of Vitamin D Affects Measures of Systemic Inflammation: Reductions in High Sensitivity C-Reactive Protein Level and Neutrophil to Lymphocyte Ratio (NLR) Distribution. J Cell Biochem 2017;118:4317-22. https://doi.org/10.1002/jcb.26084.

[85] Karkeni E, Morin SO, Tayeh BB, Goubard A, Josselin E, Castellano R, et al. Vitamin D controls tumor growth and CD8+ T Cell infiltration in breast cancer. Front Immunol 2019;10:112. https://doi.org/10.3389/fimmu.2019.01307.

[86] Chadha MK, Fakih M, Muindi J, Tian L, Mashtare T, Johnson CS, et al. Effect of 25hydroxyvitamin D status on serological response to influenza vaccine in prostate cancer patients. Prostate 2011;71:368-72. https://doi.org/10.1002/pros.21250.

[87] Gralinski LE, Sheahan TP, Morrison TE, Menachery VD, Jensen K, Leist SR, et al. Complement activation contributes to severe acute respiratory syndrome coronavirus pathogenesis. MBio 2018;9:1-15. https://doi.org/10.1128/mBio.01753-18.

[88] Risitano AM, Mastellos DC, Huber-Lang M, Yancopoulou D, Garlanda C, Ciceri F, et al. Complement as a target in COVID-19? Nat Rev Immunol 2020;20:343-4. https://doi.org/10.1038/s41577-020-0320-7.

[89] Fabbri A, Infante M, Ricordi C. Editorial - Vitamin D status: a key modulator of innate immunity and natural defense from acute viral respiratory infections. Eur Rev Med Pharmacol Sci 2020;24:4048-52. https://doi.org/10.26355/eurrev_202004_20876. 
[90] Fung TS, Liu DX. Coronavirus infection, ER stress, apoptosis and innate immunity. Front Microbiol 2014;5:1-13. https://doi.org/10.3389/fmicb.2014.00296.

[91] Hansdottir S, Monick MM, Lovan N, Powers L, Gerke A, Hunninghake GW. Vitamin D Decreases Respiratory Syncytial Virus Induction of NF- $\mathrm{B}$-Linked Chemokines and Cytokines in Airway Epithelium While Maintaining the Antiviral State. J Immunol 2010;184:965-74. https://doi.org/10.4049/jimmunol.0902840.

[92] Pender MP. CD8+ t-cell deficiency, epstein-barr virus infection, vitamin d deficiency, and steps to autoimmunity: A unifying hypothesis. Autoimmune Dis 2012;1. https://doi.org/10.1155/2012/189096.

[93] Moon C. Fighting COVID-19 exhausts T cells. Electron Lett 2020;56:264-264. https://doi.org/10.1049/el.2020.0604.

[94] Zheng M, Gao Y, Wang G, Song G, Liu S, Sun D, et al. Functional exhaustion of antiviral lymphocytes in COVID-19 patients. Cell Mol Immunol 2020;17:533-5. https://doi.org/10.1038/s41423-020-0402-2.

[95] Cao W, Li T. COVID-19: towards understanding of pathogenesis. Cell Res 2020;30:3679. https://doi.org/10.1038/s41422-020-0327-4.

[96] Rubinsztein DC, Codogno P, Levine B. Autophagy modulation as a potential therapeutic target for diverse diseases. Nat Rev Drug Discov 2012;11:709-30. https://doi.org/10.1038/nrd3802.

[97] Regla-Nava JA, Nieto-Torres JL, Jimenez-Guardeño JM, Fernandez-Delgado R, Fett C, Castaño-Rodríguez C, et al. Severe Acute Respiratory Syndrome Coronaviruses with Mutations in 
the E Protein Are Attenuated and Promising Vaccine Candidates. J Virol 2015;89:3870-87. https://doi.org/10.1128/jvi.03566-14.

[98] Xiao L, Sakagami H, Miwa N. ACE2: The key molecule for understanding the pathophysiology of severe and critical conditions of COVID-19: Demon or angel? Viruses 2020;12:2002-3. https://doi.org/10.3390/v12050491.

[99] Bourgonje AR, Abdulle AE, Timens W, Hillebrands JL, Navis GJ, Gordijn SJ, et al. Angiotensin-converting enzyme 2 (ACE2), SARS-CoV-2 and the pathophysiology of coronavirus disease 2019 (COVID-19). J Pathol 2020;251:228-48. https://doi.org/10.1002/path.5471.

[100] Li Y, Zhou W, Yang L, You R. Physiological and pathological regulation of ACE2, the SARS-CoV-2 receptor. Vol. 157. Elsevier Ltd; 2020. https://doi.org/10.1016/j.phrs.2020.104833.

[101] Imai Y, Kuba K, Rao S, Huan Y, Guo F, Guan B, et al. Angiotensin-converting enzyme 2 protects from severe acute lung failure. Nature 2005;436:112-6. https://doi.org/10.1038/nature03712.

[102] Gracia-Ramos AE. Is the ACE2 Overexpression a Risk Factor for COVID-19 Infection? Arch Med Res 2020;51:345-6. https://doi.org/10.1016/j.arcmed.2020.03.011.

[103] Machado CDS, Ferro Aissa A, Ribeiro DL, Antunes LMG. Vitamin D supplementation alters the expression of genes associated with hypertension and did not induce DNA damage in rats. J Toxicol Environ Heal - Part A Curr Issues 2019;82:299-313. https://doi.org/10.1080/15287394.2019.1592044. 
[104] Mailhot G, White JH. Vitamin D and immunity in infants and children. Nutrients 2020;12:1-29. https://doi.org/10.3390/nu12051233.

[105] Li YC, Qiao G, Uskokovic M, Xiang W, Zheng W, Kong J. Vitamin D: A negative endocrine regulator of the renin-angiotensin system and blood pressure. J Steroid Biochem Mol Biol 2004;89-90:387-92. https://doi.org/10.1016/j.jsbmb.2004.03.004.

[106] Wu YH, Tseng CP, Cheng ML, Ho HY, Shih SR, Chiu DTY. Glucose-6-phosphate dehydrogenase deficiency enhances human coronavirus 229E infection. J Infect Dis 2008;197:812-6. https://doi.org/10.1086/528377.

[107] Hansdottir S, Monick MM, Hinde SL, Lovan N, Look DC, Hunninghake GW. Respiratory Epithelial Cells Convert Inactive Vitamin D to Its Active Form: Potential Effects on Host Defense. J Immunol 2008;181:7090-9. https://doi.org/10.4049/jimmunol.181.10.7090.

[108] Sacco RE, Nonnecke BJ, Palmer M V., Waters WR, Lippolis JD, Reinhardt TA. Differential expression of cytokines in response to respiratory syncytial virus infection of calves with high or low circulating 25-hydroxyvitamin D 3. PLoS One 2012;7. https://doi.org/10.1371/journal.pone.0033074.

[109] ClinicalTrials.gov. Identifier: NCT04536298. A Cluster-Randomized, Double-Blind, Placebo-Controlled Study to Evaluate the Efficacy of Vitamin D3 Supplementation to Reduce Disease Severity in Persons With Newly Diagnosed COVID-19 Infection and to Prevent Infection $\begin{array}{lll}\text { in } & \text { Household } & \text { Members }\end{array}$ https://www.clinicaltrials.gov/ct2/show/NCT04536298?cond=vitamin+d+and+covid-

$19 \&$ draw=2\&rank=1 (accessed November 30, 2020). 
[110] ClinicalTrials.gov Identifier: NCT04385940. Improving Vitamin D Status in the $\begin{array}{llll}\text { Management } & \text { of } & \text { COVID-19 }\end{array}$ https://www.clinicaltrials.gov/ct2/show/NCT04385940?cond=vitamin+d+and+covid-

$19 \&$ draw $=2 \&$ rank=2 $($ accessed November 30, 2020).

[111] ClinicalTrials.gov Identifier: NCT04386044. Investigating the Role of Vitamin D in the $\begin{array}{llll}\text { Morbidity } & \text { of } & \text { COVID-19 } & \text { Patients }\end{array}$ https://www.clinicaltrials.gov/ct2/show/NCT04386044?cond=vitamin+d+and+covid19\&draw=2\&rank=3 (accessed November 30, 2020).

[112] ClinicalTrials.gov Identifier: NCT04628000. Baseline Vitamin D Deficiency and COVID19 Disease Severity 2020. https://www.clinicaltrials.gov/ct2/show/NCT04628000?cond=vitamin+d+and+covid$\underline{19 \& d r a w=2}$ (accessed November 30, 2020).

[113] ClinicalTrials.gov Identifier: NCT04407286. Vitamin D Testing and Treatment for COVID 19 2020. https://www.clinicaltrials.gov/ct2/show/NCT04407286?cond=vitamin+d+and+covid$\underline{19 \& d r a w=2}$ (accessed November 30, 2020).

[114] ClinicalTrials.gov Identifier: NCT04482673. Vitamin D Supplementation in the Prevention and Mitigation of COVID-19 Infection (VitD-COVID19) 2020. https://www.clinicaltrials.gov/ct2/show/NCT04482673? cond=vitamin $+\mathrm{d}+$ and+covid$19 \&$ draw $=2 \&$ rank=6 (accessed November 30, 2020). 
[115] ClinicalTrials.gov Identifier: NCT04407572. Evaluation of the Relationship Between Zinc Vitamin D and b12 Levels in the Covid-19 Positive Pregnant Women 2020. https://www.clinicaltrials.gov/ct2/show/NCT04407572?cond=vitamin+d+and+covid-

$19 \&$ draw $=2$ (accessed November 30, 2020).

[116] ClinicalTrials.gov Identifier: NCT04502667. Efficacy of Vitamin D Treatment in Pediatric $\begin{array}{lllll}\text { Patients Hospitalized by } & \text { COVID-19 }\end{array}$ https://www.clinicaltrials.gov/ct2/show/NCT04502667?cond=vitamin+d+and+covid$19 \& d r a w=2 \&$ rank $=9$ (accessed November 30, 2020).

[117] ClinicalTrials.gov Identifier: NCT04535791. Efficacy of Vitamin D Supplementation to Prevent the Risk of Acquiring COVID-19 in Healthcare Workers (COVID-19) 2020. https://www.clinicaltrials.gov/ct2/show/NCT04535791?cond=vitamin+d+and+covid-

$19 \&$ draw $=2 \&$ rank $=7$ (accessed November 30, 2020).

[118] ClinicalTrials.gov Identifier: NCT04449718. Vitamin D Supplementation in Patients With COVID-19 2020. https://www.clinicaltrials.gov/ct2/show/NCT04449718?cond=vitamin+d+and+covid$\underline{19 \& d r a w=2 \& r a n k=10}($ accessed November 30, 2020).

[119] ClinicalTrials.gov Identifier: NCT04363840. The LEAD COVID-19 Trial: Low-risk, Early Aspirin and Vitamin D to Reduce COVID-19 Hospitalizations (LEAD COVID-19) 2020. https://www.clinicaltrials.gov/ct2/show/NCT04363840?cond=vitamin+d+and+covid19\&draw $=2($ accessed November 30, 2020). 
[120] ClinicalTrials.gov Identifier: NCT04370808. VITACOV: Vitamin D Polymorphisms and $\begin{array}{lllll}\text { Severity } & \text { of } & \text { COVID-19 } & \text { Infection }\end{array}$ https://doi.org/https://www.clinicaltrials.gov/ct2/show/NCT04370808?cond=vitamin+d+and+co vid-19\&draw $=2$.

[121] ClinicalTrials.gov Identifier: NCT04483635. Preventing COVID-19 With High-dose $\begin{array}{llll}\text { Vitamin } & \text { D } & \text { Supplements } & \text { (PROTECT) }\end{array}$ https://www.clinicaltrials.gov/ct2/show/NCT04483635? cond=vitamin+d+and+covid$19 \&$ draw $=2$ (accessed November 30, 2020).

[122] ClinicalTrials.gov Identifier: NCT04403932. Increased Risk of Severe Coronavirus Disease 2019 in Patients With Vitamin D Deficiency (COVIT-D) 2020. https://www.clinicaltrials.gov/ct2/show/NCT04403932?cond=vitamin+d+and+covid$19 \&$ draw $=2 \&$ rank=14 (accessed November 30, 2020).

[123] ClinicalTrials.gov Identifier: NCT04487951. N-terminal Pro B-type Natriuretic Peptide and Vitamin D Levels as Prognostic Markers in COVID-19 Pneumonia 2020. https://www.clinicaltrials.gov/ct2/show/NCT04487951?cond=vitamin+d+and+covid$\underline{19 \& d r a w=2}$ (accessed November 30, 2020).

[124] ClinicalTrials.gov Identifier: NCT04519034. Vitamin D Status and Immune-inflammatory Status in Different UK Populations With COVID-19 Infection 2020. https://www.clinicaltrials.gov/ct2/show/NCT04519034?cond=vitamin+d+and+covid$19 \&$ draw $=2 \&$ rank=16 (accessed November 30, 2020). 
[125] ClinicalTrials.gov Identifier: NCT04525820. High Dose Vitamin-D Substitution in

Patients With COVID-19: a Randomized Controlled, Multi Center Study (VitCov) 2020. https://www.clinicaltrials.gov/ct2/show/NCT04525820?cond=vitamin+d+and+covid-

$\underline{19 \& d r a w=1}$ (accessed November 30, 2020).

[126] ClinicalTrials.gov Identifier: NCT04334005. Vitamin D on Prevention and Treatment of COVID-19

(COVITD-19) 2020.

https://www.clinicaltrials.gov/ct2/show/NCT04334005? cond=vitamin+d+and+covid-

$19 \&$ draw $=2$ (accessed November 30, 2020).

[127] ClinicalTrials.gov Identifier: NCT04394390. Do Vitamin D Levels Really Correlated With Disease Severity in COVID-19 Patients? (COVIDVIT) 2020. https://www.clinicaltrials.gov/ct2/show/NCT04394390?cond=vitamin+d+and+covid-

19\&draw=2\&rank=19 (accessed November 30, 2020).

[128] ClinicalTrials.gov Identifier: NCT04351490. Impact of Zinc and Vitamin D3 Supplementation on the Survival of Aged Patients Infected With COVID-19 (ZnD3-CoVici) 2020. https://www.clinicaltrials.gov/ct2/show/NCT04351490?cond=vitamin+d+and+covid-

$19 \&$ draw $=2 \&$ rank=20 $($ accessed November 30, 2020).

[129] ClinicalTrials.gov Identifier: NCT04579640. Trial of Vitamin D to Reduce Risk and Severity of COVID-19 and Other Acute Respiratory Infections (CORONAVIT) 2020. https://www.clinicaltrials.gov/ct2/show/NCT04579640? cond=vitamin+d+and+covid-

$19 \&$ draw $=2 \&$ rank=21 (accessed November 30, 2020).

[130] ClinicalTrials.gov Identifier: NCT04459247. Short Term, High Dose Vitamin D $\begin{array}{llll}\text { Supplementation } & \text { for } & \text { COVID-19 } & \text { (SHADE) }\end{array}$ 
https://www.clinicaltrials.gov/ct2/show/NCT04459247?cond=vitamin+d+and+covid-

$19 \&$ draw $=2 \&$ rank=22 (accessed November 30, 2020).

[131] ClinicalTrials.gov Identifier: NCT04335084. A Study of Hydroxychloroquine, Vitamin C,

Vitamin D, and Zinc for the Prevention of COVID-19 Infection (HELPCOVID-19) 2020. https://www.clinicaltrials.gov/ct2/show/NCT04335084?cond=vitamin+d+and+covid-

$19 \& d r a w=2($ accessed November 30, 2020).

[132] ClinicalTrials.gov Identifier: NCT04344041. COvid-19 and Vitamin D Supplementation: a Multicenter Randomized Controlled Trial of High Dose Versus Standard Dose Vitamin D3 in $\begin{array}{llll}\text { High-risk } & \text { COVID-19 } & \text { Patients } & \text { (CoVitTrial) }\end{array}$ https://www.clinicaltrials.gov/ct2/show/NCT04344041? cond=vitamin $+\mathrm{d}+$ and + covid$\underline{19 \& d r a w=2}$ (accessed November 30, 2020).

[133] ClinicalTrials.gov Identifier: NCT04552951. Effect of Vitamin D on Morbidity and $\begin{array}{lllll}\text { Mortality } & \text { of } & \text { the } & \text { COVID-19 }\end{array}$ https://www.clinicaltrials.gov/ct2/show/NCT04552951?cond=vitamin+d+and+covid-

$19 \&$ draw $=2$ (accessed November 30, 2020).

[134] ClinicalTrials.gov Identifier: NCT04435119. Covid-19 and Vitamin D in Nursing-home (COVIT-EHPAD) 2020. https://www.clinicaltrials.gov/ct2/show/NCT04435119?cond=vitamin+d+and+covid$\underline{19 \& d r a w=2 \& \text { rank }=26}$ (accessed November 30, 2020).

[135] ClinicalTrials.gov Identifier: NCT04621058. Efficacy of Vitamin D Treatment in $\begin{array}{lllll}\text { Mortality } & \text { Reduction } & \text { Due }\end{array}$ 
https://www.clinicaltrials.gov/ct2/show/NCT04621058?cond=vitamin+d+and+covid-

$19 \&$ draw $=2 \&$ rank $=27$ (accessed November 30, 2020).

[136] ClinicalTrials.gov Identifier: NCT04395768. International ALLIANCE Study of $\begin{array}{llllll}\text { Therapies to Prevent } & \text { Progression of } & \text { COVID-19 } & \end{array}$ https://www.clinicaltrials.gov/ct2/show/NCT04395768?cond=vitamin+d+and+covid-

$19 \&$ draw $=2 \&$ rank $=28$ (accessed November 30, 2020).

[137] ClinicalTrials.gov Identifier: NCT04476680. Reducing Asymptomatic Infection With $\begin{array}{llllll}\text { Vitamin } & \text { D in } & \text { Coronavirus }\end{array}$ https://www.clinicaltrials.gov/ct2/show/NCT04476680?cond=vitamin+d+and+covid-

$\underline{19 \& d r a w=2 \& \text { rank }=29}$ (accessed November 30, 2020).

[138] ClinicalTrials.gov Identifier: NCT04411446. Cholecalciferol to Improve the Outcomes of COVID-19 Patients (CARED) 2020. https://www.clinicaltrials.gov/ct2/show/NCT04411446?cond=vitamin+d+and+covid$19 \&$ draw $=2 \&$ rank $=30$ (accessed November 30, 2020).

[139] ClinicalTrials.gov Identifier: NCT04596657. Vitamin D3 Supplementation to Prevent Respiratory Tract Infections 2020. https://www.clinicaltrials.gov/ct2/show/NCT04596657?cond=vitamin+d+and+covid$19 \&$ draw $=2 \&$ rank $=31$ (accessed November 30, 2020).

[140] ClinicalTrials.gov Identifier: NCT04489628. Tele-health Enabled Clinical Trial for COVID-19 2020. https://www.clinicaltrials.gov/ct2/show/NCT04489628?cond=vitamin+d+and+covid$19 \&$ draw $=2 \&$ rank $=32$ (accessed November 30, 2020). 
[141] ClinicalTrials.gov Identifier: NCT04476745. The Effect of D3 on Selected Cytokines Involved in Cytokine Storm in the Covid-19 Uninfected Jordanian People 2020. https://www.clinicaltrials.gov/ct2/show/NCT04476745? cond=vitamin $+\mathrm{d}+$ and + covid-

$19 \&$ draw $=2 \&$ rank $=33$ (accessed November 30, 2020).

[142] ClinicalTrials.gov Identifier: NCT04565392. Study of Famotidine With Vitamins C and D for Pandemic $\quad$ Coronavirus $\quad$ (CDFCOV19) 2020. https://www.clinicaltrials.gov/ct2/show/NCT04565392?cond=vitamin+d+and+covid$19 \& d r a w=2 \& r a n k=34$ (accessed November 30, 2020).

[143] ClinicalTrials.gov Identifier: NCT04609423. Cod Liver Oil for Covid-19 Prevention Study 2020. https://www.clinicaltrials.gov/ct2/show/NCT04609423?cond=vitamin+d+and+covid$19 \&$ draw $=2 \&$ rank $=35$ (accessed November 30, 2020).

[144] Passeron T, Bouillon R, Callender V, Cestari T, Diepgen TL, Green AC, et al. Sunscreen photoprotection and vitamin $\mathrm{D}$ status. $\mathrm{Br} \quad \mathrm{J}$ Dermatol 2019;181:916-31. https://doi.org/10.1111/bjd.17992. 